\title{
Immunoblot analysis of cholesterol side-chain cleavage cytochrome $P-450$ and adrenodoxin in corpora lutea of cyclic and late-pregnant sheep*
}

\author{
R. J. Rodgers $\uparrow$, M. R. Waterman $\ddagger$, E. R. Simpson $\ddagger \S$ and R. R. Magness $₫$
}

Cecil H. and Ida Green Center for Reproductive Biology Sciences, Departments of $\ddagger$ Biochemistry, $\S$ Obstetrics and Gynecology, and $\uparrow$ Pediatrics, University of Texas Health Science Center at Dallas, Dallas, Texas 75235-9051, U.S.A.

\begin{abstract}
Summary. The specific contents of cytochrome $\mathrm{P}-450_{\mathrm{scc}}$ and adrenodoxin in corpora lutea of late pregnant sheep were, respectively, $1 / 5$ and $1 / 8$ that of corpora lutea of the oestrous cycle, suggesting lower steroidogenic enzyme capacity in the former. The contents of Complex $\mathrm{V}$ proteins were also lower in the corpora lutea of late pregnancy. It was observed in the immunoblots of both Complex V and cytochrome P-450 $0_{\text {scc }}$ that immunoreactive bands of molecular weights lower than the native proteins were present in the samples from corpora lutea of late pregnancy, indicative of degradation of the native enzymes. It is concluded that corpora lutea of sheep during late pregnancy have a much lower enzyme capacity for steroidogenesis than do those of the oestrous cycle (mid-luteal phase) due to a reduction in the content of cytochrome $\mathrm{P}-450_{\mathrm{scc}}$ and adrenodoxin. The reduction in the levels of steroidogenic enzyme proteins appears to be unspecific and probably reflects an overall demise in mitochondrial functions.
\end{abstract}

Keywords: cholesterol side-chain cleavage cytochrome P-450; adrenodoxin; corpus luteum; pregnancy; sheep

\section{Introduction}

It is well established that elevated plasma concentrations of progesterone are necessary for maintenance of pregnancy in sheep. Progesterone is secreted by the corpus luteum which, if removed during the first 50 days of gestation (total gestational period 145-150 days) will cause abortion of the fetus. If removal is after 50 days of gestation the pregnancy will generally continue (Casida \& Warwick, 1945) because the placenta is then able to produce progesterone in amounts sufficient for the maintenance of the pregnancy (Linzell \& Heap, 1968; Ricketts \& Flint, 1980). Although the corpus luteum is not necessary after Day 50 of gestation it persists throughout pregnancy. Relatively little is known about luteal steroidogenic enzyme capacity in late pregnancy but it would appear that the corpus luteum contributes much less to maternal plasma progesterone concentrations than does the placenta (Bedford et al., 1972), since the concentrations of progesterone in the ovarian venous plasma and the ovarian progesterone secretion rates are reduced drastically in sheep in late gestation (Moore et al., 1972; Harrison \& Heap, 1978; Flint et al., 1983). In the present study we have used Western immunoblot techniques to measure the amounts of cholesterol side-chain cleavage cytochrome P-450 (cytochrome P-450 ${ }_{\text {scc }}$ ), the mitochondrial rate-limiting enzyme in the conversion of cholesterol to progesterone, and its electron donor, adrenodoxin, in corpora lutea of late pregnant sheep. 


\section{Materials and Methods}

Tissues. Ovaries were collected from multiparous mixed Western breeds of sheep under barbiturate (pentobarbitone) anaesthesia. Corpora lutea, which appeared to be fully formed and functional, based upon their size and colour, from mid-oestrous cycle non-pregnant ewes $(\mathrm{N}=5)$ and corpora lutea from ewes $(\mathrm{N}=5)$ late in pregnancy (133 \pm 4 days; mean \pm s.e.m.) were obtained. All animals had a single unilateral corpus luteum. Gestation length was determined from the day of mating (Day 0 ) and confirmed by the crown-rump length of the fetus. Corpora lutea were quickly frozen in liquid nitrogen stored frozen $\left(-70^{\circ} \mathrm{C}\right)$ until the day of analysis and then thoroughly homogenized with a glass homogenizer in phosphate-buffered $(0.1 \mathrm{M}, \mathrm{pH} 7.4)$ saline containing 5 mM-ethyleneglycol-bis- $\beta$ aminoethylether $N, N^{\prime}$-tetraacetic acid (EGTA), $10 \mathrm{~mm}$-dithiothreitol, $0.1 \mathrm{~m}$-leupeptin, 0.2 mM-phenylmethylsulphonylfluoride (PMSF) and $1 \%$ sodium dodecyl sulphate (SDS) at $10 \mathrm{ml} / \mathrm{g}$ tissue. The homogenates were sonicated (pulsed, $1 \mathrm{~min}$ ) and then centrifuged $(800 \mathrm{~g})$ to remove any tissue debris.

The protein concentrations of the supernatants were determined by the method of Lowry et al. (1951) and the yield of protein from corpora lutea of both cyclic and late-pregnant ewes was similar (115.4 \pm s.e.m. 19 versus $140 \cdot 2 \pm 5 \cdot 7 \mu \mathrm{g} / \mathrm{mg}$ wet weight). The specific contents of cytochrome P-450 ${ }_{\text {sce }}$, adrenodoxin and Complex V (Stigall et al., 1977) were determined by Western immunoblot analyses.

Immunoblotting. Tissue homogenates $(50 \mu \mathrm{g}$ protein), molecular weight standards (Bio-Rad Laboratories, Richmond, CA, U.S.A.), purified standards and samples of corpora lutea from cattle and rats that were useful for identification of specific proteins were each mixed with an equal volume of Tris buffer ( $\mathrm{pH} 6.8,50 \mathrm{~mm}$ ) containing $2 \%$ SDS, $10 \%$ glycerol, $0.4 \mathrm{M}$-mercaptoethanol, 2 mm-ethylenediamine-tetra-acetic acid (EDTA) and $0.05 \%$ bromophenol blue and boiled for $10 \mathrm{~min}$. Proteins were then separated according to their molecular weight by electrophoresis on polyacrylamide gels $(10 \%$ for cytochrome $\mathbf{P}-450$ sce and Complex $\mathrm{V}$ and $15 \%$ for adrenodoxin) containing SDS. The separated proteins were then electroblotted onto nitrocellulose paper for $12-18 \mathrm{~h}$ at $4{ }^{\circ} \mathrm{C}$ in $20 \%$ methanol, $20 \mathrm{~mm}$-Tris base and $150 \mathrm{~mm}$-glycine at $175 \mathrm{~mA}$. Nitrocellulose blots were incubated with $5 \%$ bovine serum albumin in Tris-buffered ( $\mathrm{pH} 7 \cdot 4,10 \mathrm{~mm})$ saline containing $0.2 \%$ Nonidet $\mathrm{P} \cdot 40\left(37^{\circ} \mathrm{C}, 45 \mathrm{~min}\right)$, and further incubated in fresh buffer containing primary rabbit IgG (room temperature, $2 \mathrm{~h}$ ). For each blot, $70 \mu \mathrm{g}$ primary IgG in $35 \mathrm{ml}$ buffer were used except for Complex $\mathrm{V}$ for which $4.2 \mu \mathrm{l}$ whole serum were used. The blots were then rinsed $(3 \times 10 \mathrm{~min})$ in Tris-buffered $(\mathrm{pH} 7 \cdot 4,10 \mathrm{~mm})$ saline containing $0 \cdot 2 \%$ Nonidet $\mathrm{P}-40,0 \cdot 25 \%$ sodium deoxycholate and $0.1 \%$ SDS and then further incubated with ${ }^{125} \mathrm{I}$-labelled goat anti-rabbit IgG in buffer containing bovine serum albumin as above (room temperature, $45 \mathrm{~min}$ ). The secondary goat anti-rabbit IgG was labelled by the lactoperoxidase method (Thorell \& Johansson, 1971) and used at $35 \times 10^{6}$ c.p.m. per $35 \mathrm{ml}$ buffer. Because more bands of protein were observed in blots of protein from corpora lutea of pregnancy, some blots were repeated with another batch of secondary IgG, yielding the same results and showing that these bands were not likely to be due to artefactual non-specific binding of the secondary IgG. Immunoblots were stained with amido black $(0.5 \mathrm{mg} / \mathrm{ml}$ in $45 \% \mathrm{methanol}$ and $10 \%$ acetic acid solution) to locate the position of the molecular weight markers. Autoradiograms of immunoblots were obtained using Kodak AR film with intensifying screens and exposure times of 6-18 h. Autoradiograms were scanned densitometrically and the intensity of the specific bands was used as an estimate of the amount of the specific protein. Earlier experiments using bovine corpora lutea had shown that the intensities of the autoradiographic bands for either cytochrome $\mathbf{P}-450_{\text {scc }}$ or adrenodoxin were linearly related to the amounts of homogenates loaded on the gels and parallel to dilutions of purified standards. The maximum amount of homogenate tested in these experiments was $50 \mu \mathrm{g}$ protein and the intensities obtained in the present experiments were not outside the linear range.

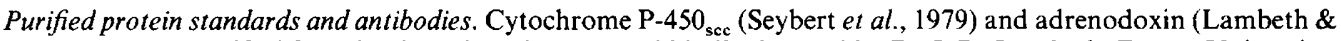
Kamin, 1979) were purified from bovine adrenal cortex and kindly donated by Dr J. D. Lambeth, Emory University, Atlanta, GA, U.S.A. Antisera were raised against these proteins and IgG fractions were prepared (DuBois et al., $1981 \mathrm{a}, \mathrm{b})$. The antisera have been used previously for immunoisolations of radiolabelled cytochrome $\mathrm{P}-450_{\text {scc }}$ and adrenodoxin from a number of steroidogenic tissues of various species (Kramer et al., 1982; Funkenstein et al., 1983, 1984; Ohashi et al., 1983; Veldhuis et al., 1986), for immunoisolations from cell-free translations of mRNA (DuBois et al., 1981 b), for tissue localization studies (Kramer et al., 1984; Rodgers et al., 1986a, b), for immunoblotting techniques (Rodgers et al., 1986c; Trzeciak et al., 1986) and for isolation of cDNA clones for cytochrome P-450 (John et al., 1984) and adrenodoxin (Okamura et al., 1985). Complex V proteins, which include the subunits of $F_{1}-$ ATPase, were purified by the methods of Stigall et al. (1977) and antisera against Complex V proteins were raised in rabbits and kindly donated by Dr G. A. Breen, University of Texas at Dallas, TX, U.S.A.

\section{Results}

The Western immunoblots for cytochrome P-450 $0_{\text {scc }}$, adrenodoxin, and Complex V proteins are shown in Figs 1, 2 and 3, respectively. The order of samples from corpora lutea of mid-oestrous cycle non-pregnant and pregnant sheep is the same on each of the immunoblots. Gestational ages 
of the pregnant ewes were $125,127,127,141$ and 145 days and are presented from left to right in all figures.

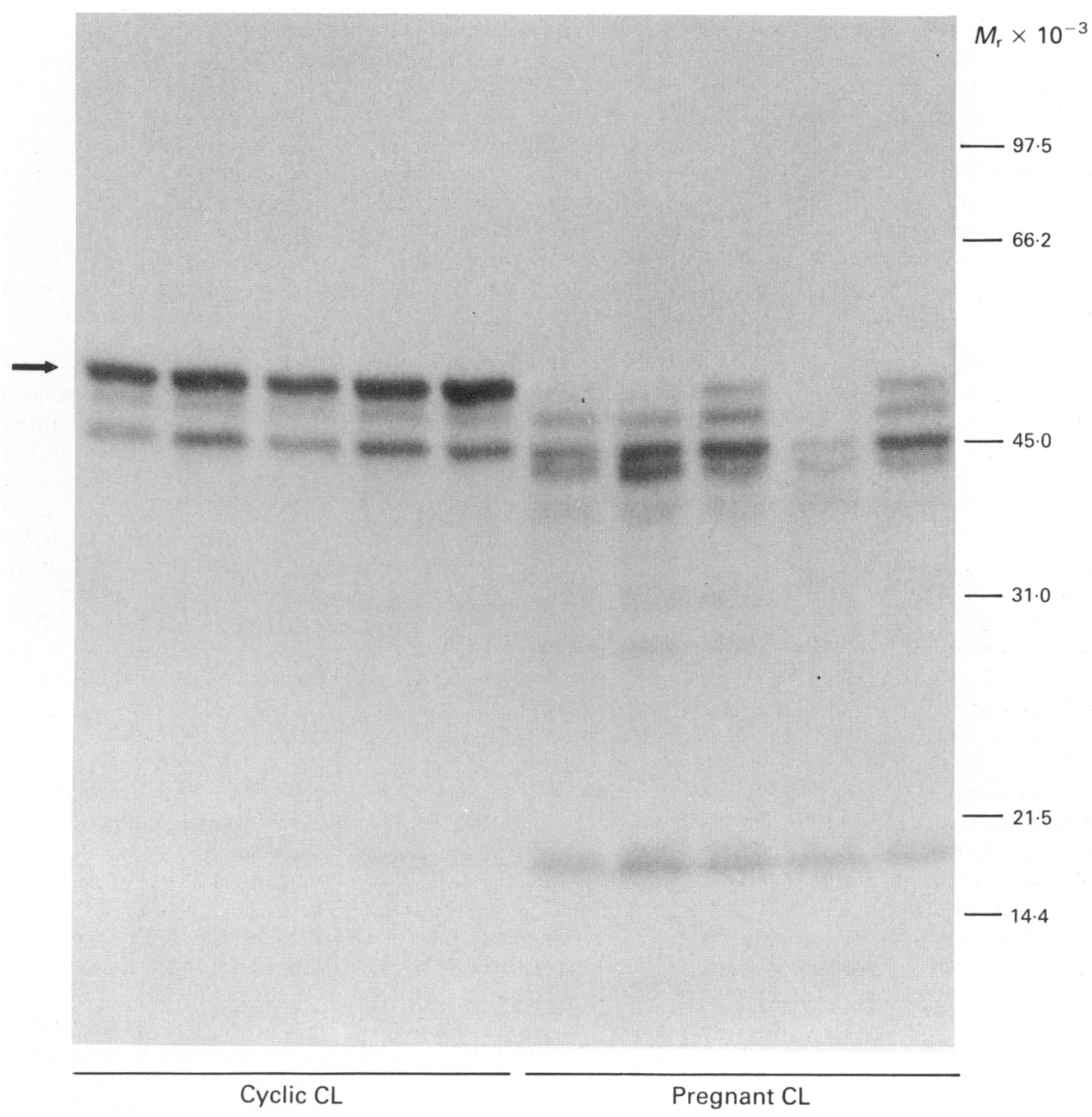

Fig. 1. Autoradiogram of Western immunoblot of proteins $(50 \mu \mathrm{g} / \mathrm{lane})$ from corpora lutea (CL) of 5 non-pregnant ewes and 5 late-pregnant ewes developed using anti-cytochrome $\mathrm{P}-450_{\text {scc }} \mathrm{IgG}$. Arrow indicates the position of purified bovine cytochrome P-450 $\mathrm{scc}_{\text {. }}$.

Cytochrome P-450 scc

The anti-cytochrome $\mathrm{P}-450_{\mathrm{scc}} \mathrm{IgG}$ reacted with proteins of $M_{\mathrm{r}} 49000$ (Fig. 1) that co-electrophoresed with purified bovine adrenal cytochrome $\mathrm{P}-450_{\mathrm{scc}}$ and with cytochrome $\mathrm{P}-450_{\mathrm{scc}}$ in homogenates of bovine and rat corpora lutea (data not shown), identifying cytochrome $\mathrm{P}-45 \mathrm{secc}_{\mathrm{scc}}$ of ovine corpora lutea in the Western immunoblot. The IgG also reacted with proteins of $M_{\mathrm{r}} 45000-46000$ from corpora lutea of the non-pregnant ewes and the late-pregnant ewes (Fig. 1). Substantial proportions of the tissue proteins were present in the same area as judged by the intensity of amido black staining. This immunoreactive band has been immunoisolated from cultured cow luteal cells and pig granulosa cells with IgG against other proteins (unpublished observations) and is not considered to be related to cytochrome $\mathrm{P}-450_{\mathrm{scc}}$. The levels of cytochrome $\mathrm{P}-450_{\mathrm{scc}}$ were similar in 


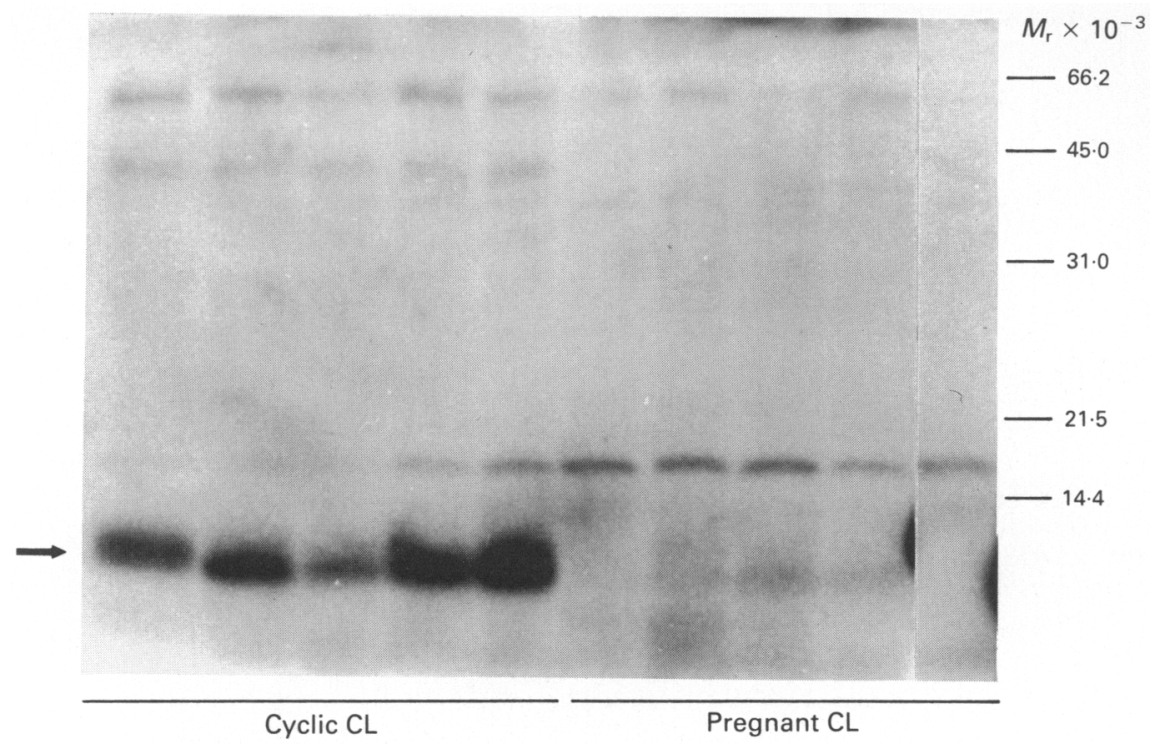

Fig. 2. Autoradiogram of Western immunoblot of proteins $(50 \mu \mathrm{g} / \mathrm{lane})$, from corpora lutea (CL) of 5 non-pregnant ewes and 5 late-pregnant ewes, developed using anti-adrenodoxin IgG. Arrow indicates the position of purified bovine adrenodoxin.

each corpus luteum of cyclic ewes and were some 7-fold greater than those of the corpora lutea of late-pregnant ewes ( $332 \pm$ s.d. 50.5 versus $48.6 \pm 38.5$ arbitrary units). Moreover, the levels in the corpora lutea of pregnant ewes were much more heterogeneous and the IgG reacted with many more proteins of low molecular weight. These low molecular weight immunoreactive proteins of pregnant ewes may have been identified by the IgG merely as non-specific interactions or more likely, as they have not been observed before in any other steroidogenic tissues, as specific interactions with proteolytic products of cytochrome $\mathrm{P}-450_{\text {sce }}$.

\section{Adrenodoxin}

The anti-adrenodoxin IgG reacted with a band of $M_{\mathrm{r}}$ approximately 12000 (Fig. 2). This band was identified as adrenodoxin since it also co-electrophoresed with the purified bovine adrenal adrenodoxin standard, which was of a slightly faster electrophoretic mobility than adrenodoxin in homogenates of bovine corpora lutea (Rodgers et al., 1986c). The levels of adrenodoxin were relatively similar among the corpora lutea of cyclic ewes and were more than 8-fold higher than those of the corpora lutea of late-pregnant ewes (213.4 $\pm 54 \cdot 6$ versus $25.2 \pm 4.8$ arbitrary units).

\section{Complex V proteins}

Complex V consists of a group of proteins from the inner mitochondrial membrane (Stigall et al., 1977) and the antiserum used was capable of recognizing some of them (Fig. 3). Three proteins were readily identified on Western blot analysis of corpora lutea of the oestrous cycle as bands corresponding to $M_{\mathrm{r}} 50000,47000$ and 34000 . The amounts of the proteins of $M_{\mathrm{r}} 50000$ and 47000 in corpora lutea of late-pregnant ewes were reduced, but that of $M_{\mathrm{r}} 34000$ was reduced in only 2 of the 5 corpora lutea of late-pregnancy. In the corpora lutea of late-pregnant ewes only 


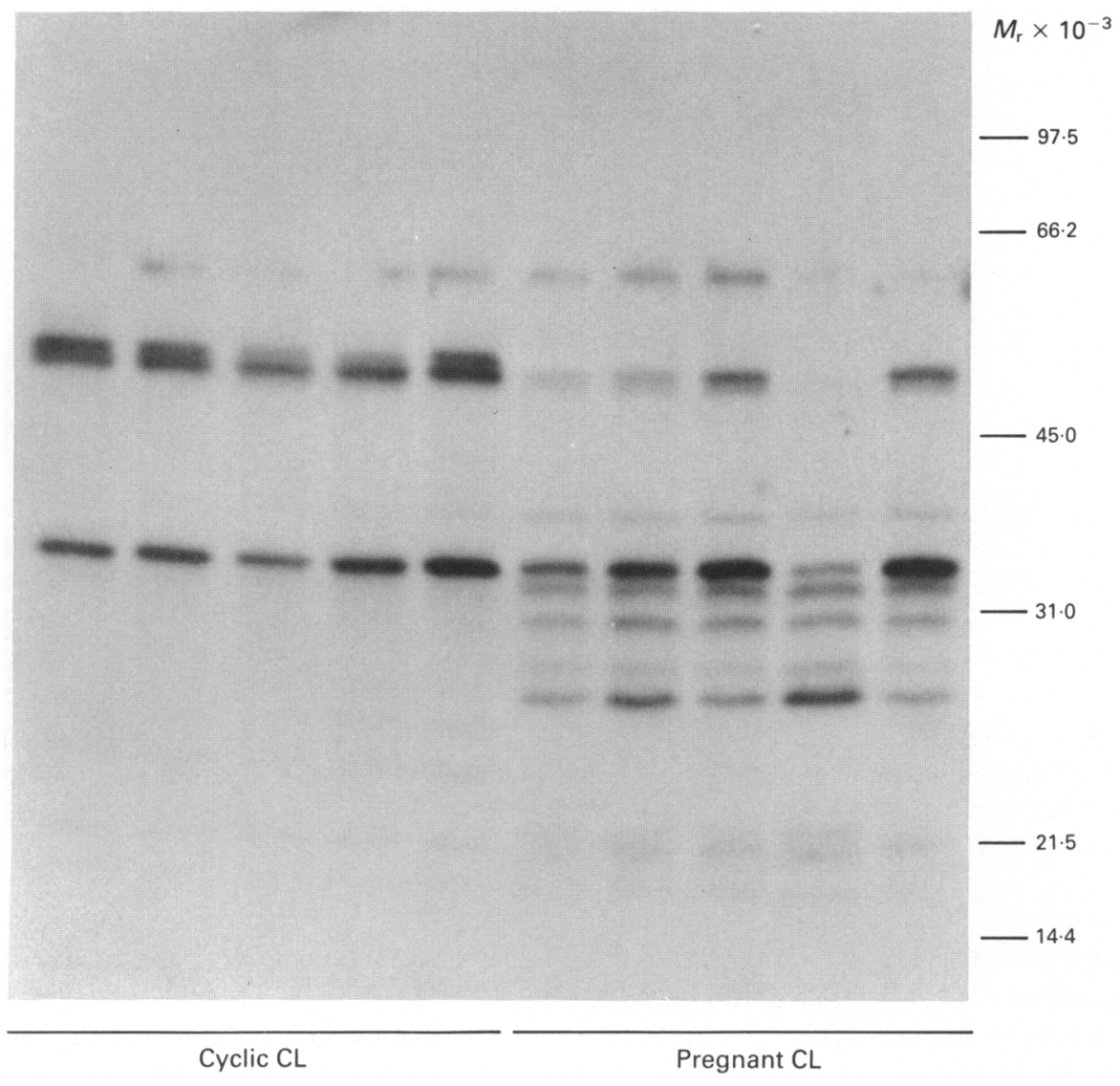

Fig. 3. Autoradiogram of Western immunoblot of proteins $(50 \mu \mathrm{g} / \mathrm{lane})$ from corpora lutea (CL) of 5 non-pregnant ewes and 5 late-pregnant ewes developed using an antiserum against Complex V proteins.

the antiserum also recognized a number of other proteins at lower molecular weights, consistent with the notion that these proteins were the degradation products of the higher molecular weight complex V proteins.

\section{Test for proteolysis artefact}

Since it is suggested from the immunoblot analyses that the inner-mitochondrial proteins of corpora lutea of late-pregnant ewes had been degraded it was necessary to determine whether this was an artefact due to the release of proteolytic enzymes upon homogenization and whose activity was not inhibited by the protease inhibitors in the buffer. Samples of corpora lutea of cyclic and late-pregnant ewes were paired and an aliquant from one sample of the pair (equivalent to $25 \mu \mathrm{g}$ protein) was taken and then combined with the other of the pair and incubated at $37^{\circ} \mathrm{C}$ for $90 \mathrm{~min}$. The samples were then subjected to immunoblotting analyses for cytochrome P- $450_{\text {scc }}$, adrenodoxin and Complex $\mathrm{V}$ proteins and compared with the results of the parent samples. There was no evidence that the enzymes of the cyclic corpora lutea were degraded by incubation with homogenates of late-pregnancy corpora lutea, suggesting that proteolytic enzymes were not active in these homogenates. 


\section{Discussion}

In the present study it was found that the specific tissue contents of the rate-limiting enzyme in the conversion of cholesterol to progesterone, cytochrome P-450 ${ }_{\mathrm{scc}}$, and its electron donor, adrenodoxin were substantially lower in sheep corpora lutea during late pregnancy than during the oestrous cycle of non-pregnant ewes. It is therefore suggested that the sheep corpus luteum has a much lower enzyme capacity for steroidogenesis in late pregnancy than during the oestrous cycle. Moreover, the reduction in the tissue content of cytochrome P-450 ${ }_{\text {scc }}$ and adrenodoxin did not appear to be specific for these proteins because the contents of other 'house-keeping' inner-mitochondrial membrane proteins were also reduced.

In the corpora lutea of the oestrous cycle the tissue levels of cytochrome $\mathrm{P}-450_{\text {scc }}$ and adrenodoxin were relatively homogeneous but in the corpora lutea of late-pregnant ewes the levels of cytochrome $\mathrm{P}-450_{\text {scc }}$ were very heterogeneous and there was no consistent pattern with advancing gestation. In the immunoblots of cytochrome $\mathrm{P}-450_{\text {scc }}$ and Complex $V$ proteins it was observed that the antibodies reacted with a number of different low molecular weight proteins in samples of corpora lutea of latepregnant ewes but not in those of corpora lutea of the non-pregnant ewes. It is possible that these proteins were breakdown products of the native enzymes. If they were then it is unlikely that they were formed by the release of proteolytic enzymes upon homogenization since the buffer used for homogenization contained proteolytic enzyme inhibitors (EGTA, dithiothreitol, leupeptin and PMSF) and no proteolytic activity could be demonstrated in the homogenates. It is therefore likely that these degradation products existed in vivo and account in part for the low levels of native enzymes in corpora lutea of late-pregnant ewes. Of course the low levels of the enzymes as a proportion of total cell proteins could be explained by a lower volume density of mitochondria. However, it is not known whether there is a reduction in the volume density of mitochondria in late pregnancy.

Mitochondria of luteal cells from the mid-luteal phase of the oestrous cycle in the sheep appear as typical 'steroidogenic mitochondria' with tubular/vesicular cristae and small electron-dense matrix granules (Bjersing et al., 1970a; Nett et al., 1976; O'Shea et al., 1979) of the type often associated with calcium storage (Hopkins, 1978). In corpora lutea of late-pregnant ewes a significant proportion of mitochondria have in their matrix large rounded granules of electron-density greater than that of the lipid droplets and of such size that they occasionally exceed $1 \mu \mathrm{m}$ in diameter and almost fill the entire area bounded by the inner membrane (Bjersing et al., 1970b; O'Shea et al., 1979). The cristae are often less well developed and are more lamellar in these mitochondria (O'Shea et al., 1979). From the present study, it is suggested that these mitochondria are functionally impaired in terms of the content of inner-mitochondrial membrane enzymes, particularly the cholesterol side-chain cleavage and Complex V proteins.

In support of this, concentrations of progesterone in the ovarian venous plasma of sheep in late gestation have been reported to be nearly one tenth that observed in early or mid-gestation (Moore et al., 1972; Flint et al., 1983). Furthermore, Harrison \& Heap (1978) reported that the ovarian secretion rate of progesterone in vivo was reduced between Days 122 and 145 of gestation when compared to early pregnant animals, or non-pregnant sheep in the luteal phase. This demise in luteal function late in gestation is also associated with a dramatic decrease in the weight and total progesterone content of the corpus luteum of pregnancy (Moore et al., 1972). Bjersing et al. (1970b) also found very low plasma concentrations of progesterone in hysterectomized ewes with corpora lutea 137-146 days old. Furthermore, these corpora lutea had mitochondria with the same type of matrix granules as observed in late pregnancy (Bjersing et al., 1970a). In the cow, corpora lutea of late pregnancy have similar mitochondrial matrix granules (Sorenson \& Singh, 1973; Singh, 1975) which increase in occurrence with length of gestation (Fields et al., 1985). Luteal cells from corpora lutea of pregnant cows produce significantly less progesterone than do those of non-pregnant animals (Weber et al., 1984), adding further support to the suggestion that these mitochondria have a reduced ability to metabolize cholesterol into progesterone due to the lack of active cholesterol side-chain cleavage enzyme. It still remains a matter of speculation as to the composition of the 
granules. If they are composed of lipid or degraded proteins or both then their formation in mitochondria would probably be as a consequence of, rather than a cause of, the reduction in the luteal content of cytochrome P-450 ${ }_{\mathrm{scc}}$ and adrenodoxin.

In conclusion, the corpus luteum of the late pregnant sheep has a much lower enzyme capacity for steroidogenesis due to a reduction in the tissue contents of cytochrome $\mathrm{P}-450_{\mathrm{scc}}$ and adrenodoxin than does that of the cyclic ewe. However, this reduction may not be specific to the steroidogenic proteins because there is a reduction in the contents of other inner-mitochondrial membrane enzymes as well as morphological changes, reflecting an overall demise in mitochondrial function in late gestation.

We thank Dr J. D. Lambeth and Dr G. A. Breen for the provision of purified proteins and antisera; Dr C. R. Mendelson for ${ }^{125}$ I-labelled goat anti-rabbit IgG; L. Ravi, S. Coultrup and J. Patterson for technical assistance; Jo Ann Killebrew, Joan Williams and Jenny Judd for typing this manuscript and NIH for grants HI7-13234, AM-28350, HD-11149, HL-34150 and HD-08783.

\section{References}

Bedford, C.A., Harrison, F.A. \& Heap, R.B. (1972) The metabolic clearance rate and production rate of progesterone and the conversion of progesterone to 20a-hydroxypregn-4-en-3-one in the sheep. $J$. Endocr. 55, 105-108.

Bjersing, L., Hay, M.F., Moor, R.M. \& Short, R.V. (1970a) Endocrine activity, histochemistry and ultrastructure of ovine corpora lutea. II Observations on regression following hysterectomy. Z. Zellforsch mikrosk. Anat. 111, 458-470.

Bjersing, L., Hay, M.F., Moor, R.M., Short, R.V. \& Deane, H.W. (1970b) Endocrine activity, histochemistry and ultrastructure of ovine corpora lutea. I Further observations on regression at the end of the oestrous cycle. Z. Zellforsch mikrosk. Anat. 111, 437-457.

Casida, L.E. \& Warwick, E.J. (1945) The necessity of the corpus luteum for maintenance of pregnancy in the ewe. J. Anim. Sci. 4, 34-36.

DuBois, R.N., Simpson, E.R., Kramer, R.E. \& Waterman, M.R. (1981a) Induction of synthesis of cholesterol side-chain cleavage cytochrome $\mathrm{P}-450$ by andrenocorticotropin in cultured bovine adrenocortical cells. J. biol. Chem. 256, 7000-7005.

DuBois, R.N., Simpson, E.R., Tuckey, J., Lambeth, J.D. \& Waterman, M.R. (1981b) Evidence for a higher molecular weight precursor of cholesterol side-chain cleavage cytochrome P-450 and induction of mitochondrial and cytosolic proteins by corticotropin in adult bovine adrenal cells. Proc. natn. Acad. Sci. U.S.A. 78, 1028-1032.

Fields, M.J., DuBois, W. \& Fields, P.A. (1985) Dynamic features of luteal secretory granules: ultrastructural changes during the course of pregnancy in the cow. Endocrinology 117, 1675-1682.

Flint, A.P.F., Burton, R.D. \& Heap, R.B. (1983) Sources of progesterone during gestation in Barbary sheep (Ammotragus lervia). J. Endocr. 98, 283-288.

Funkenstein, B., Waterman, M.R., Masters, B.S.S. \& Simpson, E.R. (1983) Evidence for the presence of cholesterol side-chain cleavage cytochrome P-450 and adrenodoxin in fresh granulosa cells. Effects of follicle-stimulating hormone and cyclic AMP on cholesterol side-chain cleavage cytochrome P-450 synthesis and activity. J. biol. Chem. 159, 8572-8577.

Funkenstein, B., Waterman, M.R. \& Simpson, E.R. (1984) Induction of synthesis of cholesterol side chain cleavage cytochrome P-450 and adrenodoxin by folliclestimulating hormone, 8-bromo-cyclic AMP, and low density lipoprotein in cultured bovine granulosa cells. J. biol. Chem. 259, 8572-8577.

Harrison, F.A. \& Heap, R.B. (1978) Progesterone secretion during pregnancy in sheep with an autotransplanted adrenal and an autotransplanted ovary. J. Reprod. Fert. 54, 153-157.

Hopkins, C.R. (1978) Structure and Function of Cells, pp. 195-203. W.B. Saunders Co. Ltd, London.

John, M.E., John, M.C., Ashley, P., MacDonald, R.J., Simpson, E.R. \& Waterman, M.R. (1984) Identification and characterization of CDNA clones specific for cholesterol side-chain cleavage cytochrome P450. Proc. natn. Acad. Sci. U.S.A. 81, 5628-5632.

Kramer, R.E., Anderson, C.M., Peterson, J.A., Simpson, E.R. \& Waterman, M.R. (1982) Adrenodoxin biosynthesis by bovine adrenal cells in monolayer culture. Induction by adrenocorticotropin. J. biol. Chem. 257, 14921-14925.

Kramer, R.E., Rainey, W.E., Funkenstein, B., Dee, A., Simpson, E.R. \& Waterman, M.R. (1984) Induction of synthesis of mitochondrial steroidogenic enzymes of bovine adrenocortical cells by analogs of cyclic AMP. J. biol. Chem. 259, 707-713.

Lambeth, J.D. \& Kamin, H. (1979) Adrenodoxin reductase-adrenodoxin complex. Flavin to ironsulfur electron transfer as the rate limiting step in the NADPH-cytochrome $\mathrm{c}$ reductase reaction. J. biol. Chem. 254, 2766-2774.

Linzell, J.L. \& Heap, R.B. (1968) A comparison of progesterone metabolism in the pregnant sheep and goat: sources of production and an estimation of uptake by some target organs. J. Endocr. 41, 433-438.

Lowry, O.H., Rosebrough, N.J., Farr, A.L. \& Randall, R.J. (1951) Protein measurement with the Folin phenol reagent. J. biol. Chem. 193, 265-275. 
Moore, N.W., Barrett, S. \& Brown, J.B. (1972) Progesterone concentrations in maternal and foetal blood plasma of ewes. J. Endocr. 53, 187-194.

Nett, T.M., McClellan, M.C. \& Niswender, G.D. (1976) Effects of prostaglandins on the ovine corpus luteum: blood flow, secretion of progesterone and morphology. Biol. Reprod. 15, 66-78.

Ohashi, M., Simpson, E.R., Mason, J.I. \& Waterman, M.R. (1983) Biosynthesis of cholesterol side-chain cleavage cytochrome $\mathbf{P}-450$ in human fetal adrenal cells in culture. Endocrinology 112, 2039-2045.

Okamura, T., John, M.E., Zuber, M.X., Simpson, E.R. \& Waterman, M.R. (1985) Molecular cloning and amino acid sequence of the precursor form of bovine adrenodoxin: evidence for a previously unidentified COOH-terminal peptide. Proc. natn. Acad. Sci. U.S.A. 82, 5707-5709.

O'Shea, J.D., Cran, D.G. \& Hay, M.F. (1979) The small luteal cell of the sheep. J. Anat. 128, 239-251.

Ricketts, A.P. \& Flint, A.P.F. (1980) Onset of synthesis of progesterone in the peripheral plasma of the pregnant ewe. $J$. Endocr. 86, 337-347.

Rodgers, R.J., Rodgers, H.F., Hall, P.F., Waterman, M.R. \& Simpson, E.R. (1986a) Immunolocalization of cholesterol side-chain cleavage cytochrome P-450 and $17 \alpha$-hydroxylase cytochrome P-450 in bovine ovarian follicles. J. Reprod. Fert. 78, 627-638.

Rodgers, R.J., Rodgers, H.F., Waterman, M.R. \& Simpson, E.R. (1986b) Immunolocalization of cholesterol side-chain cleavage cytochrome $\mathrm{P}-450$ and ultrastructural studies of bovine corpora lutea. $J$. Reprod. Fert. 78, 639-652.

Rodgers, R.J., Waterman, M.R. \& Simpson, E.R. (1986c) Cytochromes $\mathrm{P}-450_{\mathrm{scc}}, \mathrm{P}-450_{17 a}$, adrenodoxin and reduced nicotinamide adenine dinucleotide phosphate-cytochrome $\mathbf{P}-450$ reductase in bovine follicles and corpora lutea. Changes in specific contents during the ovarian cycle. Endocrinology 118, 1366-1374.

Seybert, D.W., Lancaster, J.R., Jr, Lambeth, J.D. \& Kamin, H. (1979) Participation of the membrane in the side-chain cleavage of cholesterol. Reconstruction of cytochrome P-450 ${ }_{\text {scc }}$ into phospholipid vesicles. $J$. biol. Chem. 254, 12088-12098.

Singh, U.B. (1975) Structural changes in the granulosa lutein cells of pregnant cows between 60 and 245 days. Acta anat. 93, 447-457.

Sorensen, V.W. \& Singh, U.B. (1973) On mitochondrial inclusions in granulosa lutein cells of pregnant cows. Experientia 29, 592-593.

Stigall, D.L., Galante, Y.N. \& Hatefi, Y. (1977) Preparation and properties of an ATP-Pi exchange complex (Complex V) from bovine heart mitochondria. J. biol. Chem. 253, 956-964.

Thorell, J.I. \& Johansson, B.G. (1971) Enzymatic iodination of polypeptides with ${ }^{125}$ I to high specific activity. Biochim. Biophys. Acta 251, 363-369.

Trzeciak, W.H., Waterman, M.R. \& Simpson, E.R. (1986) Synthesis of the cholesterol side-chain cleavage enzymes in cultured rat ovarian granulosa cells: induction by follicle-stimulating hormone and dibutyryl adenosine 3',5'-monophosphate. Endocrinology 119, 323-330.

Veldhuis, J.D., Rodgers, R.J., Dee, A. \& Simpson, E.R. (1986) The insulin like growth factor, somatomedin $\mathrm{C}$, induces the synthesis of cholesterol side-chain cleavage cytochrome $\mathrm{P}-450$ and adrenodoxin in ovarian cells. J. biol. Chem. 261, 2499-2502.

Weber, D.M., Roberts, R.F., Romrell, L. \& Fields, M.J. (1984) Biochemically and morphologically different luteal cells in late pregnant cows. Biol. Reprod. (Suppl 1) 30, 91, Abstr.

Received 8 December 1987 